\title{
Dynamics of sedimentary basins and underlying lithosphere at plate boundaries: the Eastern Mediterranean
}

\author{
Fadi Henri Nader, Ralf Littke, Liviu C. Matenco, and Panos Papanastasiou (Guest editors)
}

Received: 20 November 2018 / Accepted: 20 November 2018

The Task Force VI of the International Lithosphere Program (ILP) concerns all scientific aspects of sedimentary basins. Our societies rely on such sedimentary basins, which provide their habitat for living (locations of major cities) and vital resources (water, food, energy). This Task Force (VI) consists of a group of scientists whose work is dedicated to the understanding of the processes that are behind the creation and evolution of the sedimentary basins - including their inherent geo-resources. Deep Earth or shallow near surface processes are therefore the target for continuously evolving and interacting academic- and industry- based research, crossing the spatial scales from nanometres to the regions and continental scales.

By developing cross-fertilisation joint-ventures between research institutes, academia and the industries in all relevant domains, the ILP Task Force VI network creates and validates novel scientific concepts for revealing the complex evolution of sedimentary basins and its impacts on topography building and geo-resources. Hence, a broad range of geological, geophysical and geochemical datasets have to be integrated and cutting-edge methodologies improved and applied to worldwide natural laboratories. In other words, the ILP Task Force VI is a platform for the integration of field studies, analytical techniques and numerical/analogue modelling aiming altogether to understand and predict the coupled orogens and sedimentary basins systems dynamics from a multi-disciplinary approach.

This modest but rather effective community of scientists (experts, scholars and students) meets at least once every year at a dedicated scientific workshop to share advances in the global sedimentary basin research. In such occasions, worldwide researchers are hosted to present results of their recent work in the broader field of the dynamics of sedimentary basins (from the underlying lithosphere to land and ocean surface), within tectonic-plates or at plate boundaries, and related analogues. The ILP Task Force on Sedimentary Basins promotes dialogue among researchers studying basin infilling and sedimentary successions, those investigating deeper basin structures, and those developing numerical and analogue models for investigating multi-scale, basin processes. In these meetings, the participation of
Young Researchers at the doctoral and post-doctoral levels is very much encouraged by, for instance, moderate student registration fees and possible grants.

This special volume of Oil \& Gas Science Technology (OGST) Journal includes the highlights of the 12th Workshop of the International Lithosphere Program Task Force VI Sedimentary Basins, which took place in Limassol (Cyprus) from the 29th of October to the 2nd of November 2017. The workshop was entitled: "Dynamics of sedimentary basins and underlying lithosphere at plate boundaries and related analogues". The location of the meeting in the vicinity of the major Eastern Mediterranean active plate boundary (separating the African, Arabian and Eurasian plates) was a stimulating environment for promoting discussions of processes related to the formation and evolution of sedimentary basins. Such sedimentary basins, located in the vicinity of major plate boundaries contain valuable resources (e.g. groundwater, hydrocarbon, ores, hydro- or geo-thermal energy) and may be the sites of devastating geohazards (e.g. earthquakes, tsunamis, landslides). In addition, they host increasingly populated areas and have, therefore, a major societal relevance.

About 59 scientists from 14 countries (China, Cyprus, Denmark, France, Germany, Greece, Hungary, Italy, Lebanon, Japan, The Netherlands, Russia, Sweden, and USA) contributed to this workshop (Fig. 1). The technical program included six thematic sessions with one keynote lecture for each, and a bouquet of 42 oral presentations and 12 posters. Out of these contributions, eight articles of different scientific disciplines have been prepared, thoroughly reviewed and finally accepted for publication in this special volume of $O G S T$.

Iannace et al. [1] contributed with an article entitled "Tectono-stratigraphic evolution of the Southern Campania Margin: a key area for the evolution of the Tyrrhenian-Apennine system" (Fig. 2 [1]). This work combined the analysis of seismic reflection profiles, borehole data, depth conversion, 3D models, balanced sections, and correlation with onshore and offshore documented geologic features to reconstruct the 3D architecture and evolution of the Southern Campania Margin and provide 


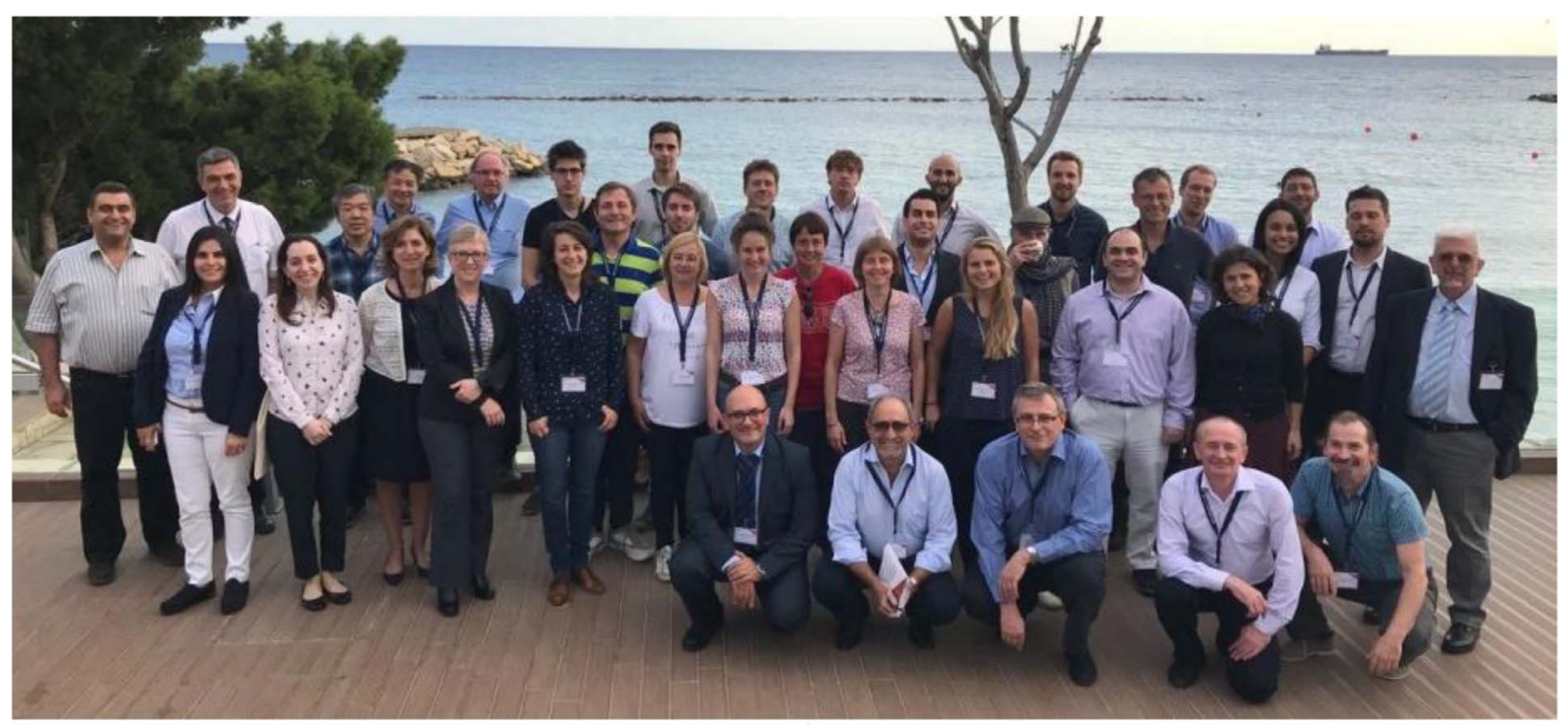

Fig. 1. Group photograph of the participants at the 12th Workshop of the International Lithosphere Program Task Force VI Sedimentary Basins, Royal Apolonia Hotel, Limassol, Cyprus, 29 October-2 November 2017.

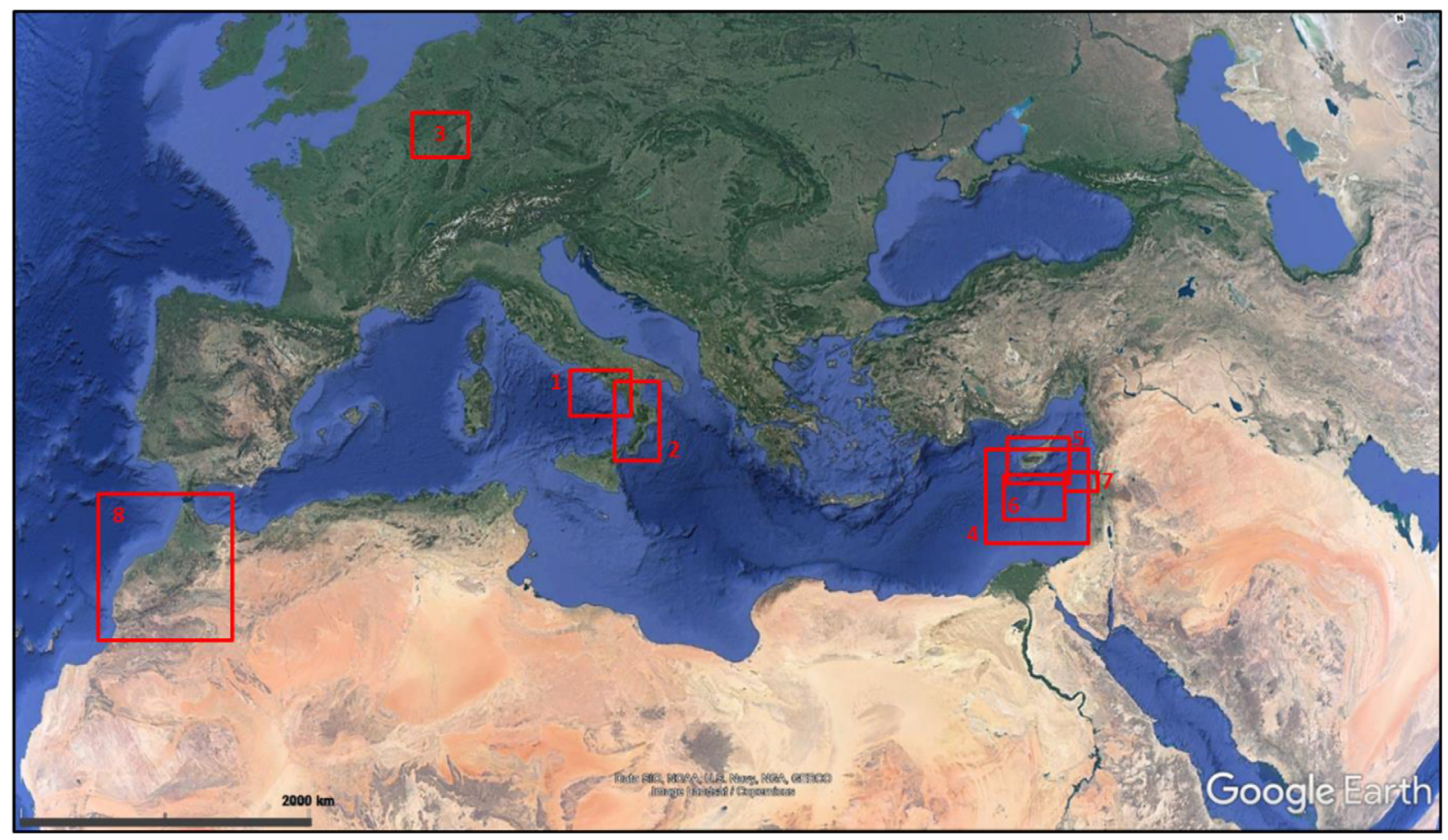

Fig. 2. Google Earth map of the Mediterranean region indicating the study areas of the varied contributions compiled in this $O G S T$ Special Volume: [1] Iannace et al.; [2] Milia et al.; [3] Claes et al.; [4] Markou \& Papanastasiou; [5] Papadimitriou et al.; [6] Grohmann et al.; [7] Nader et al.; [8] Mounir et al.

age constrains for the migration of the Calabria terrane. Milia and Torrente [2] contribution, entitled "Extensional Messinian basins in the Central Mediterranean (Calabria, Italy; Fig. 2 [2]): new stratigraphic and tectonic insights", reveals some peculiar element of the geological evolution of the Central Mediterranean. Claes et al. [3] change the scale of investigation with an article entitled "Coupled experimental/numerical workflow for assessing quantitative diagenesis and dynamic porosity/permeability evolution in calcite-cemented sandstone reservoir rocks" 
(Luxembourg sandstone Formation; Fig. 2 [3]). Here, a new, coupled laboratory and numerical methodology to investigate reservoir properties at the micro-scale and solutions for upscaling the results are presented.

Markou and Papanastasiou [4] contribution, entitled "Petroleum geomechanics modelling in the Eastern Mediterranean basin: Analysis and application of fault stress mechanics", presents a methodology for identifying the critically stressed faults of the Aphrodite gas field (Fig. 2 [4]), and whether these faults are active or remain dormant under current stress conditions and how the stability may change in reservoir injection or depletion conditions. Papadimitriou et al. [5] investigated onshore Cyprus in order to discuss the tectonostratigraphic evolution of Cenozoic basins of the Northern Tethys - actually, the Northern margin of the Levant Basin (Fig. 2 [5]). Grohmann et al. [6] contributed with an article entitled: "Source rock characterization of mesozoic to cenozoic organic matter rich marls and shales of the Eratosthenes Seamount, Eastern Mediterranean Sea" (Fig. 2 [6]). This paper presents the geochemical and petrological data of 122 investigated samples of Late Cretaceous to Messinian age, adding valuable information on source rock intervals of the underexplored deep water frontier area of the Eratosthenes Seamount (ESM), offshore Cyprus. Nader et al. [7] present new data on the Levant Basin. They provide key geological characteristics of a special geological feature, the Saida-Tyr Platform, which lies along the eastern margin of the Levant Basin, offshore Lebanon (Fig. 2 [7]). They discuss the implications of tectono-stratigraphic studies for hydrocarbon exploration. Last but not least, Mounir et al. $[8]$ present data on spectacular karstic formations in Morocco with a contribution entitled "The Middle Atlas Geological karsts forms: Towards Geosites characterization" (Fig. 2 [8]). These authors invite the readers to dive into the karst of the Middle Atlas for which they are in the process of nominating them to be enlisted on the UNESCO Geosites.

\section{References}

1 Iannace P., Torrente M.M., Milia A. (2018) Tectono-stratigraphic evolution of the Southern Campania Margin: a key area for the evolution of the Tyrrhenian-Apennine system, Oil \& Gas Science and Technology - Rev IFP Energies nouvelles 73, 39.

2 Milia A., Torrente M.M. (2018) Extensional Messinian basins in the Central Mediterranean (Calabria, Italy): new stratigraphic and tectonic insights, Oil Gas Sci. Technol. - Rev. IFP Energies nouvelles $\mathbf{7 3}, 45$.

3 Claes S., Nader F.H., Youssef S. (2018) Coupled experimental/ numerical workflow for assessing quantitative diagenesis and dynamic porosity/permeability evolution in calcite-cemented sandstone reservoir rocks, Oil Gas Sci. Technol. - Rev. IFP Energies nouvelles $\mathbf{7 3}, 36$.

4 Markou N., Papanastasiou P. (2018) Petroleum geomechanics modelling in the Eastern Mediterranean basin: analysis and application of fault stress mechanics, Oil Gas Sci. Technol. Rev. IFP Energies nouvelles 73, 57.

5 Papadimitriou N., Deschamps R., Symeou V., Souque C., Gorini C., Nader F.H., Blanpied C. (2018) The tectonostratigraphic evolution of Cenozoic basins of the Northern Tethys: The Northern margin of the Levant Basin, Oil Gas Sci Technol. - Rev. IFP Energies nouvelles 73, 77.

6 Grohmann S., Fietz S.W., Littke R., Bou Daher S., RomeroSarmiento M.F., Nader F.H., Baudin F. (2018) Source rock characterization of mesozoic to cenozoic organic matter rich marls and shales of the Eratosthenes Seamount, Eastern Mediterranean Sea, Oil Gas Sci. Technol. - Rev. IFP Energies nouvelles 73, 49.

7 Nader F.H., Inati L., Ghalayini R., Hawie N., Bou Daher S. (2018) Key geological characteristics of the Saida-Tyr Platform along the eastern margin of the Levant Basin, offshore Lebanon: implications for hydrocarbon exploration, Oil Gas Sci. Technol. - Rev. IFP Energies nouvelles 73, 50.

8 Mounir S., Saoud N., Charroud M., Mounir K., Choukrad J. (2019) The Middle Atlas Geological karsts forms: Towards Geosites characterization, Oil Gas Sci. Technol. - Rev. IFP Energies nouvelles 74, 17. 